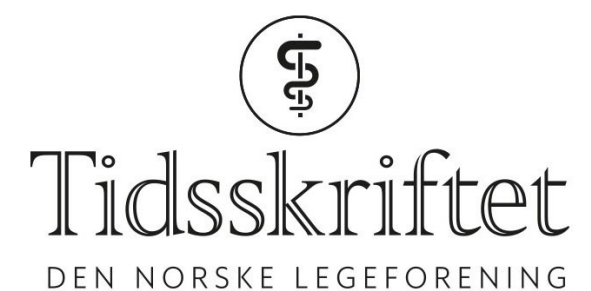

DEN NORSKE LEGEFORENING

\title{
For høyt innhold av vitamin D i kosttilskudd?
}

DEBATT

\section{LILLIAN REITER}

Lillian Reiter (f. 1977) er cand.pharm. og ph.d. ved RELIS Sør-Øst, Avdeling for farmakologi, Klinikk for laboratoriemedisin, Oslo universitetssykehus.

Forfatter har fylt ut ICMJE-skjemaet og oppgir ingen interessekonflikter.

\section{HANNE STENBERG-NILSEN}

Hanne Stenberg-Nilsen (f. 1964) er cand.pharm. og spesialrådgiver ved RELIS Sør-Øst, Avdeling for farmakologi, Klinikk for laboratoriemedisin, Oslo universitetssykehus.

Forfatter har fylt ut ICMJE-skjemaet og oppgir ingen interessekonflikter.

Reseptfrie kosttilskudd med høye doser vitamin D har nylig kommet i salg på apotek. Produktene inneholder like høye doser som reseptbelagte vitamin D-preparater. Inntak av høye doser vitamin D uten oppfølging hos lege kan være helseskadelig.

Hovedkildene til vitamin D i norsk kosthold er fet fisk, beriket smør og margarin, i tillegg til tran (1). Ifølge en landsomfattende kostholdsundersøkelse fra 2010 er det gjennomsnittlige

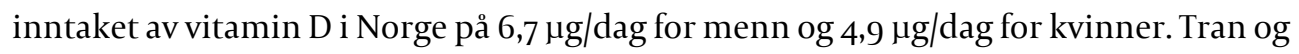
andre kosttilskudd er ikke med i disse beregningene (2).

\section{Vitamin D-tilskudd og helseskadelige effekter}

Det har lenge vært anerkjent at vitamin D er viktig for benhelsen, både som profylakse og $\mathrm{i}$ behandlingen av blant annet osteoporose og osteomalasi. I den reviderte nordiske næringsstoffanbefalingen konkluderer ekspertgruppen med at det kun er tilstrekkelig vitenskapelig belegg til å fastslå at det er beskyttende effekt av vitamin D på benhelse, totaldødelighet og risiko for fall (1).

Imidlertid har man de siste årene diskutert om vitamin D også har andre helseeffekter. Vitamin D blir anbefalt (ofte i høye doser) for blant annet forebygging av kreft, kardiovaskulære sykdommer, diabetes og autoimmune sykdommer (3). Data fra observasjonsstudier av disse indikasjonene er imidlertid sprikende, og det er ikke etablert tilstrekkelig vitenskapelig bevis for at det er en årsakssammenheng mellom vitamin D-nivå og disse tilstandene. Det er også funnet $ø$ kt risiko for morbiditet, særlig kardiovaskulær sykdom, både ved lave og høye doser av vitamin D (3). Et for høyt vitamin D-inntak kan medføre hyperkalsemi, som igjen kan føre til nyrestein, muskelsvakhet, tretthet, depresjon, forstyrrelser av hjerterytme, kvalme og oppkast $(1,3,4)$. 


\section{Endringer i regelverket for kosttilskudd}

Maksimumsinnhold for vitaminer i kosttilskudd er fastsatt i kosttilskuddsforskriften (5). I mai 2017 fastsatte Helse- og omsorgsdepartementet Forskrift om endring i forskrift om kosttilskudd og innførte nye maksimumsgrenser for vitamin D per døgn inndelt i fire alderstrinn, 1-3 år, 3-11 år, 11-18 år og over 18 år (6, 7). Her er for eksempel maksimumsgrensen for barn fra 11 til 18 år satt til $40 \mu g$, og for voksne til $80 \mu g$ per døgn. Kosttilskudd som inneholder mer enn den anbefalte døgndosen for barn og opptil 18 år i én oppmålt enhet, skal merkes med «kan være helseskadelig for barn» $(6,7)$. Før endringen var det maksimale tillatte innholdet av vitamin D i kosttilskudd $20 \mu$ g per døgndose (6).

Kosttilskudd er generelt ikke pålagt samme regelverk som legemidler når det gjelder krav til dokumentasjon av effekt og sikkerhet. Etter lovendringen kan kosttilskudd nå inneholde like mye vitamin D som reseptbelagte vitamin D-preparater, for eksempel Divisun 800 IE/20oo IE og Nycoplus vitamin $D_{3} 800$ IE $(8,9)$.

\section{Anbefalte døgndoser og maksimumsgrense}

Med denne endringen er det tillatt å selge kosttilskudd med innhold som tilsvarer maksimumsgrensen for vitamin D i kosttilskudd for både barn, unge (11-18 år) og voksne. Imidlertid er det ingen endringer i vurderinger av anbefalte døgndoser.

I de nordiske næringsstoffanbefalingene tilråder man et daglig inntak på $10 \mu g$ (40o IE) vitamin D. For eldre er det anbefalte inntaket av vitamin D på $20 \mu \mathrm{g} / \mathrm{dag}$ (80o IE). Disse inntaksanbefalingene er basert på at befolkningen bør ligge på et vitamin D-nivå målt som 25-hydroksy-vitamin D på $>50 \mathrm{nmol} / \mathrm{l}$, noe som er sammenfallende med konklusjonen fra amerikanske National Academy of Medicine (1).

Den daglige inntaksanbefalingen er den mengden vitamin D som antas å være tilstrekkelig for at $97,5 \%$ av befolkningen oppnår adekvat 25 -hydroksy-vitamin D-serumkonsentrasjon (recommended dietary allowance, RDA) (1). National Academy of Medicine anbefaler imidlertid et daglig inntak på 6oo IE ved 70 år og yngre og 8oo IE hos voksne over 70 år.

Kosttilskuddet fra Nycoplus (10) inneholder 4-8 ganger så mye vitamin D som anbefalt $\mathrm{i}$ Norge - 3200 IE ( $80 \mu \mathrm{g}$ ) versus 400 IE/80o IE (10/20 $\mu \mathrm{g})$. Vitenskapskomiteen for mattrygghet (VKM) har vurdert at det øvre tolerable inntaksnivået til vitamin D for voksne er 4 ooo IE per dag (11).

\section{Faktorer som påvirker opptak av vitamin D}

Inntaksanbefalingen (RDA) fra National Academy of Medicine er omdiskutert. Et punkt som er blitt kritisert, er at man i anbefalingene ikke tar hensyn til kroppsvekt, selv om man antar at overvektige trenger 2-3 ganger høyere doser enn normalvektige personer. Videre har nylig publiserte studier vist at til tross for god etterlevelse besto vitamin D-mangelen. Det virker som om variabiliteten i serumkonsentrasjonen etter vitamin D-inntak (doseresponse variability) er mye større enn tidligere antatt. Serumkonsentrasjonen påvirkes av flere faktorer, for eksempel alder, kjønn, diett, soleksponering, fysisk aktivitet, kroppsvekt, hudpigmentering, genetiske faktorer med mer (12).

\section{Vitamin D-mangel bør behandles av lege}

Kosttilskudd som inneholder høye doser kan nå kjøpes uten at det er påvist vitamin Dmangel. Vi er skeptiske til salg av høydoserte kosttilskudd til kunder på apotek uten resept og uten nylig serumkonsentrasjonsmåling. Det er stor variasjon mellom dose av vitamin D og oppnådd serumkonsentrasjon.

Pasienter med vitamin D-mangel, der høye doser er indisert, bør følges opp av lege for å monitorere effekt og eventuelle bivirkninger. Behandling med reseptpliktige legemidler sikrer at lege er involvert. Bruk av de nye høydoserte kosttilskuddene uten at lege er 
informert, og dermed gitt mulighet til oppfølging, kan utgjøre en mulig risiko for uheldige effekter av vitamin D.

\section{LITTERATUR:}

1. Brustad M, Meyer HE. Vitamin D - hvor mye er nok, og er mer bedre for helsen? Tidsskr Nor Legeforen 2014; 134: 726 - 8. [PubMed][CrossRef]

2. Totland TH, Melnæs BK, Lundberg-Hallen N et al. Nordkost 3. En landsomfattende kostholdsundersøkelse blant menn og kvinner. https://helsedirektoratet.no/Lists/Publikasjoner/Attachments/301/Norkost-3-en-landsomfattende-kost holdsundersokelse-blant-menn-og-kvinner-i-norge-i-alderen-18-70-ar-2010-11-IS-20oo.pdf (28.11.2017).

3. Manson JE, Bassuk SS. Vitamin D research and clinical practice: at a crossroads. JAMA 2015; 313: 1311 - 2. [PubMed][CrossRef]

4. Havnen GC, Mørch-Johansen G. Retningslinjer for bruk av vitamin D og risiko ved høye doser. https://relis.no/Publikasjoner/2013/Retningslinjer_for_bruk_av_vitamin_D_og_risiko_ved_hoye_do $\operatorname{ser} /(23.11 .2017)$

5. Statens legemiddelverk. Vitaminer ikke lenger klassifisert som legemidler. https://legemiddelverket.no/nyheter/vitaminer-ikke-lenger-klassifisert-som-legemidler (28.11.2017).

6. Mattilsynet. Revisjon av nasjonale maksimumsgrenser for vitaminer og mineraler i kosttilskudd separate maksimumsgrenser.

https://www.mattilsynet.no/mat_og_vann/spesialmat_og_kosttilskudd/kosttilskudd/revisjon_av_na sjonale_maksimumsgrenser_for_vitaminer_og_mineraler_i_kosttilskudd__separate_maksimumsg renser.24618 (23.11.2017).

7. Helse- og omsorgsdepartementet. FOR-2017-05-30-671. Forskrift om endring i forskrift om kosttilskudd. https://lovdata.no/dokument/LTI/forskrift/2017-05-30-671 (23.11.2017).

8. Statens legemiddelverk. Preparatomtale (SPC) Divisun.

https://www.legemiddelsok.no/sider/default.aspx?searchqueryDivisun\&f-

Han;MtI;Vir;ATC;Var;Mar;Mid;Avr;gen;par;\&pane=o (28.11.2017).

9. Statens legemiddelverk. Preparatomtale (SPC) Nycoplus vitamin $\mathrm{D}_{3}$. https://www.legemiddelsok.no/sider/default.aspx?searchqueryvitamin\%2oD3\&fHan;MtI;Vir;ATC;Var;Mar;Mid;Avr;gen;par;\&pane=o (28.11.2017).

10. Nycoplus. Viten om vitaminer.

https://nycoplus.no/endelig-lanserer-nycoplus-kosttilskudd-hoyere-dose-d-vitamin/(23.11.2017).

11. Vitenskapskomiteen for mattrygghet. Vurdering av maksimumsgrenser for vitamin A og vitamin D i kosttilskudd.

https://vkm.no/risikovurderinger/allevurderinger/vurderingavmaksimumsgrenserforvitaminaogvita mindikosttilskudd.4.2994e95b15cc545071651fog.html (28.11.2017).

12. Veugelers PJ, Pham TM, Ekwaru JP. Optimal vitamin D supplementation doses that minimize the risk for both low and high serum 25-hydroxyvitamin D concentrations in the general population. Nutrients 2015; 7: 10189-208. [PubMed][CrossRef]

Publisert: 21. desember 2017. Tidsskr Nor Legeforen. DOI: 10.4045/tidsskr.17.1013

Mottatt 17.11.2017, godkjent 28.11.2017.

(C) Tidsskrift for Den norske legeforening 2020. Lastet ned fra tidsskriftet.no 